\title{
Copper-mediated arylation with arylboronic acids: Facile and modular synthesis of triarylmethanes
}

\author{
H. Surya Prakash Rao* and A. Veera Bhadra Rao
}

\author{
Full Research Paper \\ Address: \\ Department of Chemistry, Pondicherry University, Pondicherry 605 \\ 014, India Telephone: +914132654411; Fax: +914132656230 \\ Email: \\ H. Surya Prakash Rao* - hspr.che@pondiuni.edu.in; \\ A. Veera Bhadra Rao - hspr.che@pondiuni.edu.in \\ * Corresponding author \\ Keywords: \\ copper; modular synthesis; triarylmethanes
}

Open Access

\author{
Beilstein J. Org. Chem. 2016, 12, 496-504. \\ doi:10.3762/bjoc. 12.49 \\ Received: 22 November 2015 \\ Accepted: 04 March 2016 \\ Published: 11 March 2016 \\ This article is part of the Thematic Series "Copper catalysis in organic \\ synthesis". \\ Guest Editor: S. R. Chemler \\ (C) 2016 Rao and Rao; licensee Beilstein-Institut. \\ License and terms: see end of document.
}

\begin{abstract}
A facile and modular synthesis of triarylmethanes was achieved in good yield via a two-step sequence in which the final step is the copper(II)-catalyzed arylation of diarylmethanols with arylboronic acids. By using this protocol a variety of symmetrical and unsymmetrical triarylmethanes were synthesized. As an application of the newly developed methodology, we demonstrate a highyielding synthesis of the triarylmethane intermediate towards an anti-breast-cancer drug candidate.
\end{abstract}

\section{Introduction}

The triarylmethanes form an exclusive group of organic molecules wherein three aryl groups are attached to the central $\mathrm{sp}^{3}$ hybridized carbon atom bearing a hydrogen atom [1-4]. Although the group can be restricted to such molecules, many closely related derivatives that have a triarylmethane motif (like those having a heteroatom attached to the central carbon atom or the central carbon is $\mathrm{sp}^{2}$ hybridized) have been included in this class [5]. Molecules with a triarylmethane motif are ubiquitous and found mainly in technologically and medicinally relevant molecules like dyes [6-9], $\mathrm{pH}$ indicators [10-12], fluorescent probes [13-18] and antibacterial drugs [19]. For example, malachite green (1) is a dye, cresol red (2) is a pH indicator and turbomycin (3) is an antibacterial medicinal drug (Figure 1).
Genuine triarylmethane 4, having three different aryl groups on the central $\mathrm{CH}$, is a proven anti-breast-cancer agent [20]. In addition to 4 , several other triarylmethanes exhibit interesting biological activity, including oestrogen receptor binding affinity [21], inhibition of hepatic cholesterol [22], inhibition of aldose reductase [23], antiproliferative [24], antiviral, cytotoxic [25], antifungal [26], anti-HIV [27-29] and antibacterial activity [30]. Although rare, there are a few natural products, for example, melanervin (5), a flavanoid bearing the triarylmethane motif [31,32].

Triarylmethanes are typically synthesized by a Friedel-Craftstype substitution of the three alkoxy groups in a trialkyl ortho- 
<smiles>CO[N+](C)=C1C=CC(=C(c2ccccc2)c2ccc(N(C)C)cc2)C=C1</smiles>

1 (malachite green)<smiles>Cc1cc(C2(c3ccc(O)c(C)c3)OS(=O)(=O)c3ccccc32)ccc1O</smiles>

2 (cresol red)<smiles>c1ccc([C](c2c[nH]c3ccccc23)c2c[nH]c3ccccc23)cc1</smiles>

3 (turbomycin)<smiles>CNCCOc1ccc(C(c2ccc(OC)cc2)c2cc3ccccc3c3ccccc23)cc1</smiles>

4 (anticancer agent)<smiles>COc1ccc(-c2cc(=O)c3c(O)c(C)c(O)c(C(c4ccccc4)c4ccccc4)c3o2)c(O)c1C</smiles>

5 (melanervin)

Figure 1: Representative examples of triarylmethanes.

formate (Scheme 1A, method 1) [33-35] or by sequential twostep addition of electron-rich aromatic nucleophiles to activated arene aldehydes followed by substitution of the resulting hydroxy group with another electron-rich aromatic compound (Scheme 1A, method 2) [36-39]. Both of the approaches are limited in scope and suffer from drawbacks such as (a) electronrich aromatic systems that are required as nucleophiles and therefore, not amenable for the synthesis of triarylmethanes with electron-withdrawing groups, (b) the regioselectivity in the substitution at the aromatic ring that depends on the ortho- or para-directing nature of the substituent and also by the steric hindrance offered by the substitution, (c) the methods are rarely modular and not suitable for the preparation of triarylmethanes with three different aryl groups, and finaly, (d) Lewis [40,41] or protic acids [42] are required to catalyze the reactions. To overcome the above-mentioned difficulties, many efforts have recently been directed towards transition metal-catalyzed crosscouplings [43-48] or $\mathrm{CH}$ arylation followed by an arylative desulfonation $[49,50]$. The coupling reactions provide an opportunity to install an unactivated aryl group on a carbon bearing two more aryl groups to synthesize the triarylmethane motif. Recently, we reported a copper-catalyzed $\mathrm{C}-\mathrm{C}$ bond formation by substitution of the labile C(4)SMe group in $4 H$-chromenes or $\mathrm{C}(3)-\mathrm{OH}$ in isoindolinones with aryl/alkenyl groups by employing the corresponding boronic acids $[51,52]$. Continuing these efforts, we designed a copper-catalyzed synthesis of a variety of triarylmethanes through substitution of $\mathrm{C}\left(\mathrm{sp}^{3}\right)-\mathrm{OH}$ in diarylmethanols with arylboronic acids (Scheme 1B). We reasoned that since diarylmethanols with two different aromatic rings can be made by a wide variety of methods [53,54] (e.g., addition of an aryl carbanion to an aryl aldehyde and a further step with a variety of aryl boronic acids), it should be possible to provide a

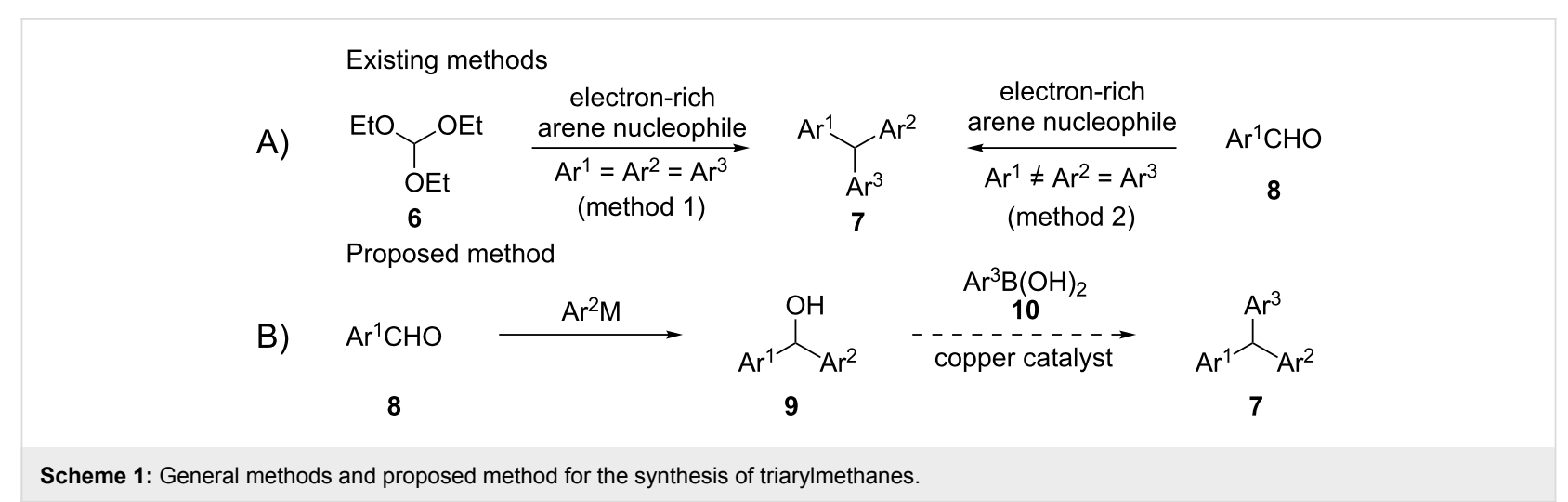


unique opportunity for the modular synthesis of unsymmetrical triarylmethanes. If successful, the method could provide an opportunity for the synthesis of a combinatorial library of the coveted molecules. Herein, we report a copper(II) triflate-catalyzed modular synthesis of triarylmethanes by employing diarylmethanols $\mathbf{9}$ and arylboronic acids 10. It is advantageous to employ a base metal catalyst such as copper(II) triflate instead of palladium [55,56] or nickel (Ni) [57] catalysts and to avoid the use of phosphine ligands as it is less expensive and more readily facilitates purification.

\section{Results and Discussion}

We selected the copper-mediated cross-coupling reaction of diphenylmethanol (9a) with phenylboronic acid (10a) for the synthesis of triphenylmethane (11a) to optimize the reaction conditions and catalyst loading. Based on our accrued experience [52], in a first attempt, we employed $\mathrm{Cu}(\mathrm{OTf})_{2}(10 \mathrm{~mol} \%)$ in refluxing 1,2-dichlorethane (DCE) to effect $\mathrm{C}-\mathrm{C}$ coupling, but the reaction provided (phenoxymethylene)dibenzene (12) as the only product formed through the $\mathrm{C}-\mathrm{O}$ coupling (Chan-Lam-Evans coupling product) [58-60] in 64\% yield.

To obtain the desired triphenylmethane (11a) as the sole product, we screened various alternative solvents (Scheme 2). Of the solvents investigated, toluene gave a mixture of triphenylmethane (11a) and the toluene-incorporated product ( $p$-tolylmethylene)dibenzene (14) in 36\% and 52\% yield, respectively (Scheme 2). Solvents like acetonitrile (polar, aprotic) and dioxane (oxygenated, aprotic) did not provide the triphenylmethane (11a). On the other hand, the higher-boiling, nonpolar chlorobenzene (Scheme 2) at $80{ }^{\circ} \mathrm{C}$ provided the coupled product triphenylmethane (11a) in $64 \%$ yield. When the reaction was conducted under oxygen atmosphere, the yield of 11a fell to $46 \%$. Under these aerobic conditions, we isolated biphenyl (13) generated through homocoupling of phenylboronic acid. Attempts to improve the yield by the use of bases such as $\mathrm{Na}_{2} \mathrm{CO}_{3}(10 \mathrm{~mol} \%)$ and $\mathrm{K}_{2} \mathrm{CO}_{3}(10 \mathrm{~mol} \%)$ were not successful. The yield of triphenylmethane (11a) was further reduced in these cases. The base was employed to trap the boric acid, which is likely to be the side product of the reaction. From the above experiments, we concluded that chlorobenzene was the most suitable solvent for the synthesis of triphenylmethane (11a).

Next, we turned our attention to evaluate different copper salts to optimize the yield of triphenylmethane (11a); these efforts have been summarized in Table 1 . We screened various $\mathrm{Cu}$ (II) catalysts such as $\mathrm{Cu}(\mathrm{OAc})_{2}(64 \%$, Table 1 , entry 1$)$, $\mathrm{Cu}\left(\mathrm{CF}_{3} \mathrm{COO}\right)_{2}\left(46 \%\right.$, Table 1 , entry 2) $\mathrm{Cu}(\mathrm{acac})_{2}(36 \%$, Table 1, entry 3), $\mathrm{CuSO}_{4} \cdot 5 \mathrm{H}_{2} \mathrm{O}\left(36 \%\right.$, Table 1, entry 4), $\mathrm{CuBr}_{2}$ (14\%, Table 1 , entry 5$), \mathrm{CuCl}_{2} \cdot 2 \mathrm{H}_{2} \mathrm{O}(24 \%$, Table 1 , entry 6$)$ and $\mathrm{CuO}$ (no reaction, Table 1 , entry 8 ), which did not provide the desired triphenylmethane (11a) in better yield. However, $20 \mathrm{~mol} \%$ of $\mathrm{Cu}(\mathrm{OTf})_{2}$ (Table 1, entry 17) delivered the desired triphenylmethane (11a) in good yield (78\%) after chromatographic purification. We screened other borderline Lewis acids such as $\mathrm{Sc}(\mathrm{OTf})_{3}, \mathrm{Yb}(\mathrm{OTf})_{3}, \mathrm{Zn}(\mathrm{OTf})_{2}$ and $\mathrm{Fe}(\mathrm{OTf})_{3}$, but the reaction did not afford triphenylmethane (11a) at all, which indicated that $\mathrm{Cu}(\mathrm{II})$ and not $\mathrm{TfOH}$ is responsible for the transformation. Thus, the optimal conditions for the copper-mediated

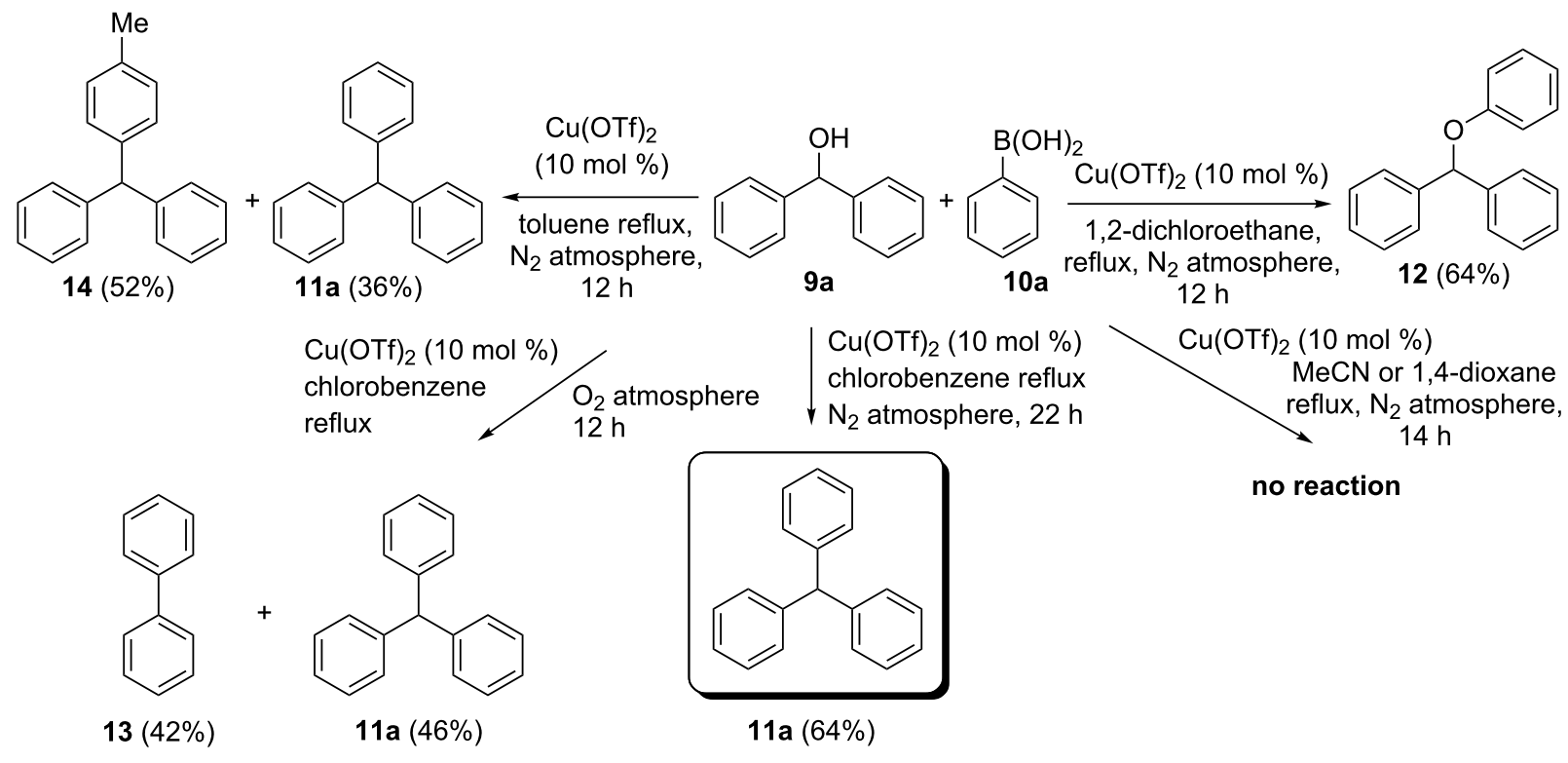

Scheme 2: Role of solvent and reaction conditions in the $\mathrm{Cu}(\mathrm{OTf})_{2}$-mediated coupling of diphenylmethanol (9a) with phenylboronic acid (10a) for the preparation of triphenylmethane (11a). 
Table 1: Screening of metal catalysts for the arylation reaction.<smiles>OC(c1ccccc1)c1ccccc1</smiles>

$9 a$<smiles>OB(O)c1ccccc1</smiles>

$10 \mathrm{a}$

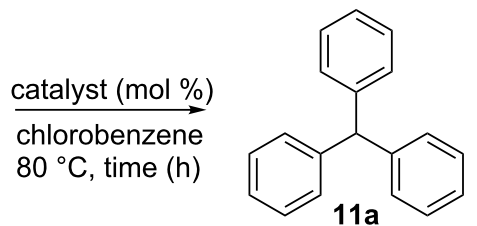

$11 a$

\begin{tabular}{|c|c|c|c|c|}
\hline Entry & Catalyst & Time (h) & Catalyst (mol \%) & Yield (\%)a \\
\hline 1 & $\mathrm{Cu}(\mathrm{OAc})_{2} \cdot \mathrm{H}_{2} \mathrm{O}$ & 21 & 10 & 64 \\
\hline 2 & $\mathrm{Cu}\left(\mathrm{OOCCF}_{3}\right)_{2}$ & 18 & 10 & 46 \\
\hline 3 & $\mathrm{Cu}(\mathrm{acac})_{2}$ & 21 & 10 & 36 \\
\hline 4 & $\mathrm{CuSO}_{4} \cdot 5 \mathrm{H}_{2} \mathrm{O}$ & 19 & 10 & 36 \\
\hline 5 & $\mathrm{CuBr}_{2}$ & 16 & 10 & 14 \\
\hline 6 & $\mathrm{CuCl}_{2} \cdot \mathrm{H}_{2} \mathrm{O}$ & 16 & 10 & 24 \\
\hline 7 & $\mathrm{Cu}(\mathrm{OTf})_{2}$ & 21 & 10 & 68 \\
\hline 8 & $\mathrm{CuO}$ & 12 & 10 & n.r. \\
\hline 9 & Cul & 21 & 10 & 42 \\
\hline 10 & $\mathrm{CuBr}$ & 21 & 10 & 14 \\
\hline 11 & $\mathrm{CuCl}$ & 19 & 10 & 28 \\
\hline 12 & $\mathrm{Cu}_{2} \mathrm{O}$ & 12 & 10 & n.r. \\
\hline 13 & $\mathrm{Cu}(\mathrm{I}) \mathrm{BrSMe}_{2}$ & 12 & 10 & n.r. \\
\hline 14 & $\mathrm{Cu}\left(\mathrm{PPh}_{3}\right)_{2} \mathrm{Br}$ & 12 & 10 & n.r. \\
\hline 15 & CuMeSal & 21 & 10 & 42 \\
\hline 16 & CuTc & 21 & 10 & 27 \\
\hline 17 & $\mathrm{Cu}(\mathrm{OTf})_{2}$ & 18 & 20 & 78 \\
\hline 18 & $\mathrm{Sc}(\mathrm{OTf})_{3}$ & 12 & 10 & n.r. \\
\hline 19 & $\mathrm{Fe}(\mathrm{OTf})_{3}$ & 12 & 10 & n.r. \\
\hline 20 & $\mathrm{Zn}(\mathrm{OTf})_{2}$ & 12 & 10 & n.r. \\
\hline 21 & $\mathrm{Yb}(\mathrm{OTf})_{3}$ & 12 & 10 & n.r. \\
\hline
\end{tabular}

coupling involve heating equimolar amounts of diphenylmethanol (9a) and phenylboronic acid (10a) in chlorobenzene at $80{ }^{\circ} \mathrm{C}$ in the presence of $20 \mathrm{~mol} \%$ of $\mathrm{Cu}(\mathrm{OTf})_{2}$ under a blanket of oxygen-free nitrogen.

Based on the above observations, we propose a mechanism for the copper-mediated coupling of phenylboronic acid with diphenylmethanol, leading to triphenylmethane and boric acid (Scheme 3). At the start of the cascade, the first step is the transmetallation of the copper(II) into phenylboronic acid to form reactive $\mathrm{PhCu}(\mathrm{OTf})(\mathbf{1 5})$ and $\mathrm{B}(\mathrm{OH})_{2}(\mathrm{OTf})$ [61]. The intermediate $\mathbf{1 5}$ then reacts with diphenylmethanol 9 to provide the intermediate 16. Formation of the intermediate $\mathbf{1 6}$ can be attributed to Lewis acidic characteristics of $\mathbf{1 5}$ and Lewis basic characteristics of diphenylmethanol (9a). The crucial $\mathrm{C}-\mathrm{C}$ bond formation with simultaneous $\mathrm{C}-\mathrm{O}$ bond cleavage subsequently occurs in $\mathbf{1 6}$ to give the triarylmethane $\mathbf{1 1}$ and copper(OH)(OTf) (17). The reaction of 17 with arylboronic acid 10 regenerates 15 and results in the formation of stable boric acid. The driving force for the triarylmethane formation is the

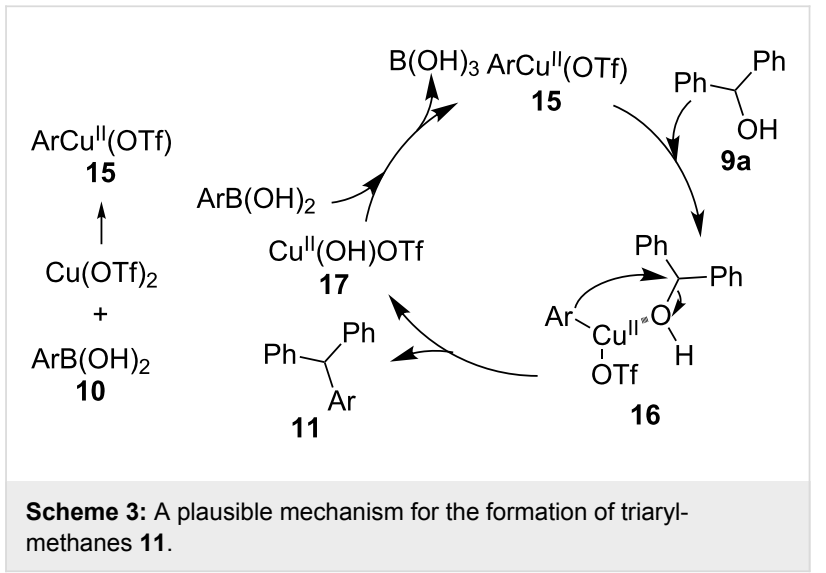

generation of a stable $\mathrm{C}-\mathrm{C}$ bond in $\mathbf{1 1}, \mathrm{Cu}-\mathrm{O}$ bond in $\mathbf{1 7}$, and boric acid at the cost of weak $\mathrm{Ar}-\mathrm{Cu}$ and $\mathrm{C}-\mathrm{OH}$ bonds in $\mathbf{1 6}$ and $\mathbf{9}$, respectively [52].

With the optimized reaction conditions in hand, we examined the scope of the cross-coupling reaction for the synthesis of a 
variety of triarylmethanes from diphenylmethanol (9a). Ten more arylboronic acids were employed in the coupling reaction and good yields (77-92\%) of the corresponding triarylmethanes $\mathbf{1 1 b}-\mathbf{k}$ were realized (Table 2). The arylboronic acids 10b-k were selected considering their structural diversity and electron density in the aryl ring. Efficient cross-coupling could be noted irrespective of the presence of strongly electron-withdrawing (10b,c to 11b,c; Table 2, entries 1 and 2), mildly electron-withdrawing (10d,e to 11d,e; Table 2, entries 3 and 4), strongly electron-donating (10f to 11f; Table 2, entry 5) or mildly electron-donating (10g to $\mathbf{1 1 g}$; Table 2 , entry 6 ) groups at the $\mathrm{C}(4)$ position of the phenyl ring. The robust nature of the protocol was demonstrated by reacting ortho-methoxyphenylboronic acid (10h) to efficiently generate the desired triarylmethane 11 h (Table 2, entry 7). The transformation showed that apart from the insensitivity towards electronic effects, the copper-mediated cross-coupling reaction is not very sensitive to steric crowding in the neighborhood of the reaction center. Next, we employed heteroaromatic boronic acids, such as furan2-ylboronic acid (10i; Table 2, entry 8), thiophen-2-ylboronic acid (10j; Table 2, entry 9) and benzo[b]thiophen-2-ylboronic acid (10k; Table 2, entry 10) in the coupling reaction and the reactions furnished the corresponding triarylmethanes $11 \mathbf{a}-\mathbf{k}$ in excellent yield. The transformations showed that heteroaromatic groups, including those bearing a sulfur atom, react efficiently to provide triarylmethanes.

However, when we employed 2,6-dimethoxyphenylboronic acid 101, surprisingly, we isolated the triarylmethane 111, in which the $\mathrm{C}-\mathrm{C}$ bond formation took place on the $\mathrm{C}(3)$ carbon of the 2,6-dimethoxyphenylboronic acid instead of the C(1) carbon, as illustrated in $\mathbf{1 1 m}$ (Scheme 4). Structure of $\mathbf{1 1 1}$ was readily confirmed on the basis of ${ }^{13} \mathrm{C}$ NMR and DEPT-135 spectra. We surmise that the initially formed, transmetallated product 18 rearranged to the more stable $\mathbf{1 8 a}$ before it could react with diphenylmethanol (9a, Scheme 4).

The scope of the copper-catalyzed coupling reaction of diarylmethanols 9b-d with phenylboronic acid (10a) was explored by changing one or both of the aryl rings in the diarylmethanol (Table 3) [62]. The copper-catalyzed reaction of phenyl(pyren1-yl)methanol (9b) with phenylboronic acid (10a) was very facile and the product triarylmethane $11 \mathrm{n}$ was obtained in $72 \%$ yield (Table 3, entry 1). Similarly, the reaction of anthracen-9yl(phenyl)methanol (9c) with phenylboronic acid (10a) provided the corresponding triarylmethane 110 in $82 \%$ yield (Table 3, entry 2). The last example in the genre is interesting, as one of the aryl rings is ferrocene in $\mathbf{1 1 p}$. The reaction of ferrocene-1-yl(phenyl)methanol (9d) with phenyboronic acid (10a) was facile and it provided diphenylmethylferrocene (11p) without any difficulty in $71 \%$ yield.

\section{Modular synthesis of triarylmethanes}

The synthetic method that we developed, through which three different aromatic rings on the central carbon can be assembled in a two-step protocol, is modular in nature. The first step is the synthesis of diarylmethanol and the second step is the replacement of the hydroxy group in the resulting diarylmethanol by a third aryl group by employing arylboronic acid under copper catalysis. As a proof of principle, we present the synthesis of

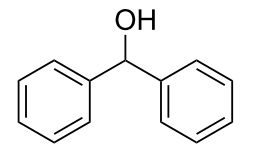

$9 a$<smiles>COc1ccccc1</smiles>

10b-k

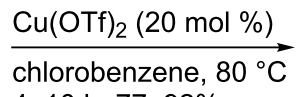
4-10 h, 77-92\%

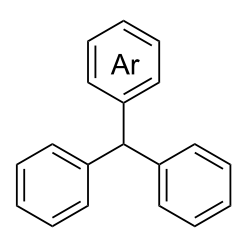

11b-k

\begin{tabular}{|c|c|c|c|c|}
\hline Entry & Ar in arylboronic acid & Triarylmethane & Time $(\mathrm{h})$ & Yield (\%) \\
\hline 1 & 10b: $4-\mathrm{CF}_{3} \mathrm{C}_{6} \mathrm{H}_{4}$ & 11b & 4 & 92 \\
\hline 2 & 10c: $4-\mathrm{FC}_{6} \mathrm{H}_{4}$ & $11 \mathrm{c}$ & 10 & 77 \\
\hline 3 & 10d: $4-\mathrm{ClC}_{6} \mathrm{H}_{4}$ & $11 d$ & 6 & 79 \\
\hline 4 & 10e: $4-\mathrm{BrC}_{6} \mathrm{H}_{4}$ & $11 e$ & 4 & 91 \\
\hline 5 & 10f: $4-\mathrm{MeOC}_{6} \mathrm{H}_{4}$ & $11 f$ & 5 & 81 \\
\hline 6 & 10g: 4- $\mathrm{MeC}_{6} \mathrm{H}_{4}$ & $11 \mathrm{~g}$ & 6 & 81 \\
\hline 7 & 10h: $2,5-(\mathrm{OMe})_{2} \mathrm{C}_{6} \mathrm{H}_{3}$ & $11 \mathrm{~h}$ & 6 & 88 \\
\hline 8 & 10i: 2-furyl & $11 i$ & 8 & 85 \\
\hline 9 & 10j: 2-thiophenyl & $11 \mathrm{j}$ & 8 & 89 \\
\hline 10 & 10k: 2-benzothiophenyl & $11 \mathrm{k}$ & 10 & 86 \\
\hline
\end{tabular}


<smiles>OC(c1ccccc1)c1ccccc1</smiles>

9a<smiles>COc1cccc(OC)c1Br</smiles>

101

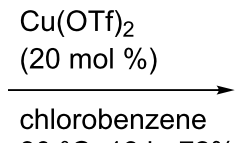
$80{ }^{\circ} \mathrm{C}, 18 \mathrm{~h}, 72 \%$<smiles>COc1ccc(C(c2ccccc2)c2ccccc2)c(OC)c1</smiles>

11I (formed)<smiles>COc1cccc(OC)c1C(c1ccccc1)c1ccccc1</smiles>

$11 \mathrm{~m}$ (expected)<smiles></smiles>

18

$\mathrm{MeO}$<smiles>[V]=[Tl]</smiles><smiles>COc1ccccc1C(=O)Br</smiles>

$18 \mathrm{a}$

Table 3: Scope of diarylmethanol $9 b-\mathbf{d}$ in the copper-catalyzed coupling reaction.

Entry Diarylmethanol<smiles>OC(c1ccccc1)c1ccc2ccc3cccc4ccc1c2c34</smiles>

$9 b$

2<smiles>OC(c1ccccc1)c1c2ccccc2cc2ccccc12</smiles>

9c

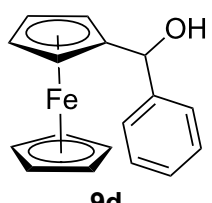

9d<smiles>OC(c1ccccc1)c1ccc2ccc3cccc4ccc1c2c34</smiles>

$9 b$
Arylboronic acid<smiles>Oc1ccccc1</smiles>

$10 \mathrm{a}$<smiles>Oc1ccccc1</smiles><smiles>[18OH]</smiles><smiles>Cc1ccccc1</smiles>

$10 \mathrm{a}$<smiles>COc1ccc(OC)cc1</smiles>

Triarylmethane $\mathrm{a}^{\mathrm{a}}$<smiles>c1ccc(C(c2ccccc2)c2ccc3ccc4cccc5ccc2c3c45)cc1</smiles>

11n (14 h, 72\%)<smiles>c1ccc(C(c2ccccc2)c2c3ccccc3cc3ccccc23)cc1</smiles>

110 (16 h, 83\%)

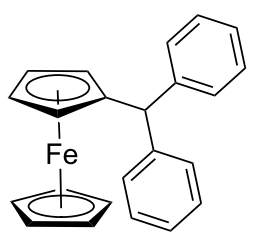

$11 \mathrm{p} \mathrm{(16} \mathrm{h,} \mathrm{71 \% )}$<smiles>COc1ccc(C(c2ccccc2)c2ccc3ccc4cccc5ccc2c3c45)cc1</smiles>

11q (16 h, 68\%) 
Table 3: Scope of diarylmethanol $\mathbf{9 b - d}$ in the copper-catalyzed coupling reaction. (continued)

5<smiles>OC(c1ccccc1)c1ccc2ccc3cccccc3c12</smiles>

$9 b$

6

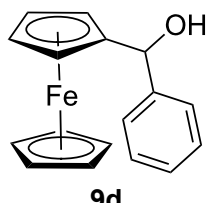

9d

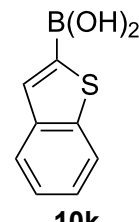

10k

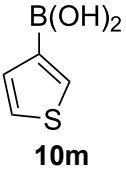<smiles>c1ccc(C(c2cc3ccccc3s2)c2ccc3ccc4cccc5ccc2c3c45)cc1</smiles>

$11 \mathrm{r}(12 \mathrm{~h}, 72 \%)$

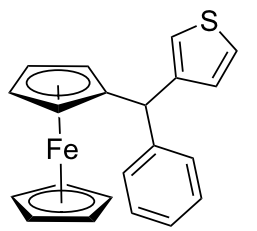

$11 \mathrm{~s}(4 \mathrm{~h}, 64 \%)$

aTime required for completion of the reaction and yield of the isolated and purified triarylmethanes are given in the parenthesis.

three examples of triarylmethanes 11q-s that bear three different aromatic rings (Table 3$)$. The copper-catalyzed coupling reaction of phenyl(pyren-1-yl)methanol (9b) with 4-methoxyphenylboronic acid (10f) and benzo[b]thiophen-2-ylboronic acid (10k) provided the respective pyrene-containing unsymmetrical triarylmethanes 11q-r in good yields (Table 3). Next, the coupling reaction of phenyl(ferrocenyl)methanol (9d) with thiophen-3-ylboronic acid $(\mathbf{1 0 m})$ provided triarylmethane $\mathbf{1 1 s}$, which has ferrocene, thiophene and phenyl rings installed on the central carbon. The triarylmethane 11s was found to be unstable when kept as a solution in hexane. However, the compound was stable as a solid for at least two months when refrigerated $\left(+5{ }^{\circ} \mathrm{C}\right)$.

To demonstrate an application of our newly developed $\mathrm{Cu}(\mathrm{OTf})_{2}$-catalyzed $\mathrm{C}-\mathrm{C}$ coupling reaction for the synthesis of triarylmethanes, we designed a synthesis of the precursor 22 (Scheme 5) for the anti-breast-cancer agent 4 (Figure 1). Any method for the synthesis of $\mathbf{4}$ needs to take into account that it has two phenyl rings with different alkoxy groups at the respec-<smiles>Brc1cc2ccccc2c2ccccc12</smiles>

19
$n$-BuLi (1.2 equiv) THF, $-78^{\circ} \mathrm{C}, 1 \mathrm{~h}$

4- $\mathrm{MeOC}_{6} \mathrm{H}_{4} \mathrm{CHO}$ (1 equiv) $-78{ }^{\circ} \mathrm{C}$ to rt, $4 \mathrm{~h}, 78 \%$<smiles>COc1ccc(C(O)c2cc3ccccc3c3ccccc23)cc1</smiles>

20<smiles>CC1(C)OB(c2ccc(OS(C)(=O)=O)cc2)OC1(C)C</smiles>

$\mathrm{Cu}(\mathrm{OTf})_{2}(20 \mathrm{~mol} \%)$ $22 \mathrm{~h}, 76 \%$

NB: o-nitrobenzyl chlorobenzene, $80^{\circ} \mathrm{C}$,<smiles>COc1ccc(C(c2ccc(OC)cc2)c2cc3ccccc3c3ccccc23)cc1</smiles>

21

\section{$h v(370 \mathrm{~nm})$}

$\mathrm{CH}_{3} \mathrm{CN} / \mathrm{H}_{2} \mathrm{O}(1: 1)$ $3 \mathrm{~h}, 86 \%$<smiles>COc1ccc(C(c2ccc(O)cc2)c2cc3ccccc3c3ccccc23)cc1</smiles>

22<smiles>CCN(C)CCOc1ccc(C(c2ccc(OC)cc2)c2cc3ccccc3c3ccccc23)cc1</smiles>

4 (anticancer agent) 
tive $\mathrm{C}(4)$ position. We reasoned that one of the aryl groups could be a part of diarylmethanol and the other of the arylboronic acid. We designed the protection of the C(4) hydroxy group in the arylboronic aicd with the photolabile 2-nitrobenzyl (NB) group, so that it can be removed without affecting the rest of the molecule. The synthesis of triarylmethane $\mathbf{2 2}$ began with the preparation of the starting diarylmethanol $\mathbf{2 0}$, which was accomplished by the addition the anion from 9-bromophenanthrene [63] 19 to 4-methoxybenzaldehdye. The resulting diarylmethanol 20 was treated with bis(pinacolato)diboron [64] 10n, which has an 2-nitrobenzyl protecting group on the phenolic hydroxy group [52]. The reaction was conducted in the presence of $20 \mathrm{~mol} \% \mathrm{Cu}(\mathrm{OTf})_{2}$ under optimized conditions, providing triarylmethane $\mathbf{2 1}$ in $\mathbf{7 6 \%}$ yield. Deprotection of the phenolic hydroxy group in $\mathbf{2 1}$ was facile under photocatalytic conditions by using UV LED lamps in wet acetonitrile. The reaction furnished the synthetic intermediate 22 in $86 \%$ yield [52]. Since the intermediate $\mathbf{2 2}$ has been previously converted into the drug candidate 4 [49], our efforts constitute a formal, alternate synthesis.

\section{Conclusion}

In conclusion, we have demonstrated a facile $\mathrm{Cu}(\mathrm{OTf})_{2}$-catalyzed synthesis of a variety of triarylmethanes from readily available diarylmethanols and arylboronic acids. This method is a novel synthetic approach for the preparation of multisubstituted triarylmethanes starting from easily preparable diarylmethanols and commercially available arylboronic acids. Structurally diverse, unsymmetrical triarylmethanes were prepared by employing this methodology. As an application to the newly developed methodology, we achieved a facile synthesis of the penultimate intermediate of an anti-breast-cancer agent. Hopefully the work described here will stimulate further work for the synthesis of a wide variety of triarylmethanes with tailor-made properties.

\section{Supporting Information}

\section{Supporting Information File 1}

Experimental procedures, characterization data, details of the NMR structural determination of all new compounds and copies of ${ }^{1} \mathrm{H},{ }^{13} \mathrm{C}$ NMR and DEPT-135 spectra for all compounds prepared.

[http://www.beilstein-journals.org/bjoc/content/ supplementary/1860-5397-12-49-S1.pdf]

\section{Acknowledgements}

H.S.P.R thanks UGC, UGC-SAP, CSIR and DST-FIST for financial assistance. A.V.R thanks CSIR for a fellowship. We thank CIF, Pondicherry University for recording spectra.

\section{References}

1. Mondal, S.; Panda, G. RSC Adv. 2014, 4, 28317-28358. doi:10.1039/c4ra01341g

2. Nair, V.; Thomas, S.; Mathew, S. C.; Abhilash, K. G. Tetrahedron 2006, 62, 6731-6747. doi:10.1016/j.tet.2006.04.081

3. Shchepinov, M. S.; Korshun, V. A. Chem. Soc. Rev. 2003, 32, 170-180. doi:10.1039/b008900I

4. Duxbury, D. F. Chem. Rev. 1993, 93, 381-433. doi:10.1021/cr00017a018

5. Oda, M.; Kawase, T.; Wei, C. Pure Appl. Chem. 1996, 68, 267-274. doi:10.1351/pac199668020267

6. Mason, C. D.; Nord, F. F. J. Org. Chem. 1951, 16, 722-727. doi:10.1021/jo01145a011

7. Ghaisas, V. V.; Kane, B. J.; Nord, F. F. J. Org. Chem. 1958, 23, 560-565. doi:10.1021/jo01098a016

8. Irie, M. J. Am. Chem. Soc. 1983, 105, 2078-2079. doi:10.1021/ja00345a075

9. Muthyala, R.; Katritzky, A. R.; Lan, X. Dyes Pigm. 1994, 25, 303-324. doi:10.1016/0143-7208(94)87017-9

10. Rottman, C.; Grader, G.; De Hazan, Y.; Melchior, S.; Avnir, D. J. Am. Chem. Soc. 1999, 121, 8533-8543. doi:10.1021/ja991269p

11. Yamaguchi, K.; Tamura, Z.; Maeda, M. Anal. Sci. 1997, 13, 521-522. doi:10.2116/analsci.13.521

12. Heger, D.; Klánová, J.; Klán, P. J. Phys. Chem. B 2006, 110, 1277-1287. doi:10.1021/jp0553683

13. Miura, T.; Urano, Y.; Tanaka, K.; Nagano, T.; Ohkubo, K.; Fukuzumi, S. J. Am. Chem. Soc. 2003, 125, 8666-8671. doi:10.1021/ja035282s

14. Haugland, R. P. Molecular Probes. The Molecular Probes Handbook. A Guide to Fluorescent Probes and Labeling Technologies, 10th ed.; Life Technologies Corporation: Eugene, USA, 2005.

15. Urano, Y.; Kamiya, M.; Kanada, K.; Ueno, T.; Hirose, K.; Nagano, T. J. Am. Chem. Soc. 2005, 127, 4888-4894. doi:10.1021/ja043919h

16. Abe, H.; Wang, J.; Furukawa, K.; Oki, K.; Uda, M.; Tsuneda, S.; Ito, Y. Bioconjugate Chem. 2008, 19, 1219-1226. doi:10.1021/bc800014d

17. Kim, H. N.; Lee, M. H.; Kim, H. J.; Kim, J. S.; Yoon, J. Chem. Soc. Rev. 2008, 37, 1465-1472. doi:10.1039/b802497a

18. Beija, M.; Afonso, C. A. M.; Martinho, J. M. G. Chem. Soc. Rev. 2009, 38, 2410-2433. doi:10.1039/b901612k

19. Parai, M. K.; Panda, G.; Chaturvedi, V.; Manju, Y. K.; Sinha, S. Bioorg. Med. Chem. Lett. 2008, 18, 289-292. doi:10.1016/j.bmcl.2007.10.083

20. Shagufta; Srivastava, A. K.; Sharma, R.; Mishra, R.; Balapure, A. K.; Murthy, P. S. R.; Panda, G. Bioorg. Med. Chem. 2006, 14, 1497-1505. doi:10.1016/j.bmc.2005.10.002

21. Bindal, R. D.; Golab, J. T.; Katzenellenbogen, J. A. J. Am. Chem. Soc. 1990, 112, 7861-7868. doi:10.1021/ja00178a003

22. Jendralla, H.; Granzer, E.; von Kerekjarto, B.; Krause, R.; Schacht, U.; Baader, E.; Bartmann, W.; Beck, G.; Bergmann, A.; Kesseler, K.; Wess, G.; Chen, L.-J.; Granata, S.; Herchen, J.; Kleine, H.; Schüssler, H.; Wagner, K. J. Med. Chem. 1991, 34, 2962-2983. doi:10.1021/jm00114a004

23. Costantino, L.; Ferrari, A. M.; Gamberini, M. C.; Rastelli, G. Bioorg. Med. Chem. 2002, 10, 3923-3931. doi:10.1016/S0968-0896(02)00318-8

24. Al-Qawasmeh, R. A.; Lee, Y.; Cao, M.-Y.; Gu, X.; Vassilakos, A.; Wright, J. A.; Young, A. Bioorg. Med. Chem. Lett. 2004, 14, 347-350. doi:10.1016/j.bmcl.2003.11.004

25. Mibu, N.; Yokomizo, K.; Uyeda, M.; Sumoto, K. Chem. Pharm. Bull. 2003, 51, 1325-1327. doi:10.1248/cpb.51.1325 
26. Schultz, T. W.; Sinks, G. D.; Cronin, M. T. D. Environ. Toxicol. 2002, 17, 14-23. doi:10.1002/tox.10027

27. Wang, P.; Kozlowski, J.; Cushman, M. J. Org. Chem. 1992, 57, 3861-3866. doi:10.1021/jo00040a027

28. Long, Y.-Q.; Jiang, X.-H.; Dayam, R.; Sanchez, T.; Shoemaker, R.; Sei, S.; Neamati, N. J. Med. Chem. 2004, 47, 2561-2573. doi:10.1021/jm030559k

29. Cushman, M.; Kanamathareddy, S.; De Clerq, E.; Schols, D.; Goldman, M. E.; Bowen, J. A. J. Med. Chem. 1991, 34, 337-342. doi:10.1021/jm00105a053

30. Parmar, V. S.; Bisht, K. S.; Jain, R.; Singh, S.; Sharma, S. K.; Gupta, S.; Malhotra, S.; Tyagi, O. D.; Vardhan, A.; Pati, H. N. Indian J. Chem., Sect. B 1996, 35, 220-232.

31. Bindal, R. D.; Katzenellenbogen, J. A. J. Med. Chem. 1988, 31 , 1978-1983. doi:10.1021/jm00118a020

32. Seligmann, O.; Wagner, H. Tetrahedron 1981, 37, 2601-2606. doi:10.1016/S0040-4020(01)98963-X

33. Pindur, U.; Müller, J. J. Heterocycl. Chem. 1987, 24, 289-290. doi:10.1002/jhet.5570240156

34. Witzel, H.; Pindur, U. J. Heterocycl. Chem. 1988, 25, 907-910. doi:10.1002/jhet.5570250339

35. Sato, T.; Higuchi, S.; Ito, K. Lett. Org. Chem. 2007, 4, 595-600. doi:10.2174/157017807782795574

36. Podder, S.; Choudhury, J.; Roy, U. K.; Roy, S. J. Org. Chem. 2007, 72, 3100-3103. doi:10.1021/jo062633n

37. Kodomari, M.; Nagamatsu, M.; Akaike, M.; Aoyama, T. Tetrahedron Lett. 2008, 49, 2537-2540. doi:10.1016/j.tetlet.2008.02.117

38. Yamamoto, Y.; Itonaga, K. Chem. - Eur. J. 2008, 14, 10705-10715. doi:10.1002/chem.200801105

39. Genovese, S.; Epifano, F.; Pelucchini, C.; Curini, M. Eur. J. Org. Chem. 2009, 1132-1135. doi:10.1002/ejoc.200801115

40. Hikawa, H.; Suzuki, H.; Azumaya, I. J. Org. Chem. 2013, 78, 12128-12135. doi:10.1021/jo402151g

41. Li, Z.; Duan, Z.; Kang, J.; Wang, H.; Yu, L.; Wu, Y. Tetrahedron 2008, 64, 1924-1930. doi:10.1016/j.tet.2007.11.080

42. Shirakawa, S.; Kobayashi, S. Org. Lett. 2007, 9, 311-314. doi:10.1021/ol062813j

43. Thirupathi, P.; Kim, S. S. Tetrahedron 2010, 66, 2995-3003. doi:10.1016/j.tet.2010.02.063

44. Shacklady-McAtee, D. M.; Roberts, K. M.; Basch, C. H.; Song, Y.-G.; Watson, M. P. Tetrahedron 2014, 70, 4257-4263. doi:10.1016/j.tet.2014.03.039

45. Harris, M. R.; Hanna, L. E.; Greene, M. A.; Moore, C. E.; Jarvo, E. R. J. Am. Chem. Soc. 2013, 135, 3303-3306. doi:10.1021/ja311783k

46. Zhou, Q.; Srinivas, H. D.; Dasgupta, S.; Watson, M. P. J. Am. Chem. Soc. 2013, 135, 3307-3310. doi:10.1021/ja312087x

47. Tabuchi, S.; Hirano, K.; Satoh, T.; Miura, M. J. Org. Chem. 2014, 79, 5401-5411. doi:10.1021/jo5010636

48. Matthew, S. C.; Glasspoole, B. W.; Eisenberger, P.; Crudden, C. M. J. Am. Chem. Soc. 2014, 136, 5828-5831. doi:10.1021/ja412159g

49. Nambo, M.; Crudden, C. M. Angew. Chem., Int. Ed. 2014, 53, 742-746. doi:10.1002/anie.201307019

50. Nambo, M.; Crudden, C. M. ACS Catal. 2015, 5, 4734-4742. doi:10.1021/acscatal.5b00909

51. Rao, H. S. P.; Rao, A. V. B. Eur. J. Org. Chem. 2014, 3646-3655. doi:10.1002/ejoc.201402003

52. Rao, H. S. P.; Rao, A. V. B. J. Org. Chem. 2015, 80, 1506-1516. doi:10.1021/j0502446k
53. Boymond, L.; Rottländer, M.; Cahiez, G.; Knochel, P. Angew. Chem., Int. Ed. 1998, 37, 1701-1703. doi:10.1002/(SICI)1521-3773(19980703)37:12<1701::AID-ANIE1701>3 .0.CO;2-U

54. Majumdar, K. K.; Cheng, C.-H. Org. Lett. 2000, 2, 2295-2298. doi:10.1021/ol006064w

55. Niwa, T.; Yorimitsu, H.; Oshima, K. Org. Lett. 2007, 9, 2373-2375. doi:10.1021/ol0708119

56. Yu, J.-Y.; Kuwano, R. Org. Lett. 2008, 10, 973-976. doi:10.1021/ol800078j

57. Cao, X.; Sha, S.-C.; Li, M.; Kim, B.-S.; Morgan, C.; Huang, R.; Yang, X.; Walsh, P. J. Chem. Sci. 2016, 7, 611-618. doi:10.1039/C5SC03704B

58. Chan, D. M. T.; Monaco, K. L.; Wang, R.-P.; Winters, M. P. Tetrahedron Lett. 1998, 39, 2933-2936. doi:10.1016/S0040-4039(98)00503-6

59. Lam, P. Y. S.; Clark, C. G.; Saubern, S.; Adams, J.; Winters, M. P.; Chan, D. M. T.; Combs, A. Tetrahedron Lett. 1998, 39, 2941-2944. doi:10.1016/S0040-4039(98)00504-8

60. Evans, D. A.; Katz, J. L.; West, T. R. Tetrahedron Lett. 1998, 39, 2937-2940. doi:10.1016/S0040-4039(98)00502-4

61. Itoh, T.; Shimizu, Y.; Kanai, M. Org. Lett. 2014, 16, 2736-2739. doi:10.1021/ol501022d

62. Furniss, B. S.; Hannaford, A. J.; Smith, P. W. G.; Tatchell, A. R. VOGEL's Textbook of Practical Organic Chemistry, 5th ed.; John Wiley \& Sons: New York, 2077; pp $523 \mathrm{ff}$.

63. Kodomari, M.; Satoh, H.; Yoshitomi, S. J. Org. Chem. 1988, 53, 2093-2094. doi:10.1021/jo00244a046

64. Lu, J.; Guan, Z.-Z.; Gao, J.-W.; Zhang, Z.-H. Appl. Organomet. Chem. 2011, 25, 537-541. doi:10.1002/aoc.1799

\section{License and Terms}

This is an Open Access article under the terms of the Creative Commons Attribution License (http://creativecommons.org/licenses/by/2.0), which permits unrestricted use, distribution, and reproduction in any medium, provided the original work is properly cited.

The license is subject to the Beilstein Journal of Organic Chemistry terms and conditions:

(http://www.beilstein-journals.org/bjoc)

The definitive version of this article is the electronic one which can be found at: doi:10.3762/bjoc. 12.49 